\title{
The Role of Network New Media Technology in the Cultivation of Innovative and Entrepreneurial Talents
}

\author{
Jun Yan \\ Jiangsu Institute of Commerce, Nanjing Jiangsu, 211168, China
}

Keywords: New media technology; Network; Innovation and entrepreneurship; Talent cultivation

\begin{abstract}
The development of online new media technology not only brings great changes to people's lifestyles and working methods, but also has a profound impact on the educational model and talent training mode of colleges and universities. Under the environment of reform and innovation in the country and participation in active entrepreneurship, how to cultivate talents with innovative spirit and entrepreneurial ability is an important task for colleges and universities to carry out education reform. It is of great significance to grasp the connotation, characteristics and corresponding training strategies of innovative and entrepreneurial talents and explore the important role of online new media technology in the cultivation of innovative and entrepreneurial talents.
\end{abstract}

\section{Introduction}

This article takes the network new media technology as an example, discusses and analyzes the new media technology of contemporary social network, further explains the reform and innovation of the network new media technology appearing in the modern environment, and advocates the development of online new media, talents must be innovative and develop. At the same time, in the craze of innovation, online new media can also recognize themselves and constantly improve and develop. The organic integration of network new media technology and innovation and entrepreneurship points out the way of network new media technology and innovation and entrepreneurship, and exerts the greatest mutual interaction, thus promoting the progress and prosperity of contemporary network communication. In recent years, due to the lack of talent in the network and new media market, the network and new media profession has become the new favorite of new universities in China. This paper combs the development status of the network and new media major, analyzes the problems existing in the relevant university network and new media professional training mode, and proposes targeted improvement suggestions.

\section{The Concept of Network New Media Technology}

For the emergence of new media, Professor Xiong Chengyu of Tsinghua University believes that "the problem of wireless mobility is extended on the basis of today's network, and secondly, there are other new media forms, computer-related can be said to be new media". Some experts also pointed out that "as long as the basic elements of the media composition are different from the traditional media, it can be called new media. Otherwise, it will be deformed or improved on the basis of the original". The Internet, known as the Fourth Media, is seen as a new media developed after the press, radio, and television and coexisting with traditional mass media. The current network new media can be understood as the form of media appearing on the basis of the network, using digital and network technologies, and being loaded on mobile terminals such as computers and mobile phones through the Internet, broadband local area networks, wireless communication networks, satellites, etc., to provide the audience with the form of communication of information and entertainment services. At the same time, the network new media has very distinct characteristics: it is diverse in form, rich in content, strong in interaction, high in coverage, and wide in impact. At the same time, in the contemporary society with rapid economic, political and cultural development, the continuous development and upgrading of science and technology has made the new media of the network show the trend of springing up, showing strong vitality and development momentum, occupying an increasingly important position in the modern media 
industry. The rapid development, wide-ranging categories, and richer content of online new media have given modern people a lot of choices in technology and media. Within this scope, the development momentum of the WeChat public platform is particularly strong and typical, and the development momentum of the WeChat navigation website involved should not be underestimated.

\section{The Importance of Online New Media Technology for Cultivating Innovative and Entrepreneurial Talents}

Cultivating relevant talents with innovative spirit and entrepreneurial spirit is a major measure for China's society to adapt to the development of economic globalization and the internationalization of talents. After joining the World Trade Organization, China has participated in market competition and international division of labor. Therefore, it is required that the talents cultivated by higher education institutions should have an international perspective. In order to meet the needs of the new situation, it is imperative to cultivate a large number of relevant talents with basic knowledge, adaptability, creative thinking and entrepreneurial ability. Cultivating talents with innovative spirit and entrepreneurial ability has become the inevitable development and reform of school education in China. Human society has changed from an industrial society to an information society, and the basic characteristics of the information age are ever-changing. This requires that the talents trained have strong resilience. A solid theoretical foundation and noble information literacy are important foundations for developing resilience. The integration of university education has become the focus of higher education development and reform, as well as the realization of China's education modernization. Even some single-scholar colleges are gradually moving towards a comprehensive direction. The integration trend of university education provides conditions and possibilities for the cultivation of innovative and entrepreneurial talents. At the same time, cultivating innovative and entrepreneurial talents is a direct result of the integrated development of university education in China. Therefore, whether it is for the development of society or for the development of education, it is necessary to cultivate talents with innovative spirit and entrepreneurial spirit.

\section{Problems in the training of network and new media professionals}

1. The training target is vague and the course structure is unbalanced. Looking at the universities that open networks and new media majors in China, from the point of view of administrative management and business guidance, most of them are placed in the discipline of journalism and communication; from the perspective of curriculum setting and training programs, the content of journalism and communication is often used and learned to a large extent; in the allocation of teachers, many college teachers come from the journalism communication profession, which leads to the new manifestation of the network and new media profession. In addition, what should be the proportion of technology in the training of network and new media professionals? What is the theoretical proportion? What are the specific training directions under the overall goal of new media talents? Few colleges and universities can make clear answers to these questions in the talent development plan. Some colleges and universities have imbalances in the overall structure of professional courses. For example, there are too many related courses in the field of journalism and communication, which is very different from traditional journalism and communication. In some colleges, there are too many software and technology courses, which form an embarrassing situation with art design and information engineering. The speed of technical software update is too fast. The four-year university training period is too long, which makes it easy for students to become tired technical craftsman. Some colleges and universities have all kinds of courses involved, and the primary and secondary are not clear, like a pot of hodgepodge, it seems to be able to meet all relevant industry positions, but in fact, students only know how to have a flaw in the fur, no competitive in the market.

2. The teacher is weak and the teaching method is single. At present, both the industry and the academic world, the application and academic talents who truly understand, research, and master the network and new media are very scarce. At present, most of the college teachers in the network 
and new media majors have transformed from news communication or information technology, but the integration of the original subject system and new majors is not realized in a short period of time. Many colleges and universities have a huge gap between the curriculum and talent training and the society's expectation of higher education, which lags behind the reality. The internal logic and connection between many subject courses are not completely open. Students are still learning mechanically and individually, and it is difficult to analyze and study social reality with the knowledge they have learned.

In terms of teacher training, only a few strong institutions have the ability to send teachers to study abroad. Most colleges and universities encourage teachers to participate in academic exchange activities for industry skills training and academic training. Many other undergraduate school teachers have expressed their willingness to go to the front line of the company. However, the school is unable to provide practical and effective policy support, and the training of dual-skilled personnel is a slap in the face. Media-related majors in some universities in the United States often hire elites from the industry to serve as visiting professors, which can not only supplement the deficiencies of the school's faculty, but also enable students to understand the latest developments in the industry front line and promote deep cooperation between schools and enterprises. This kind of flexible teacher structure is worth learning from, but many high-education thresholds and low-paying benefits employed by part-time teachers in many universities in China have discouraged many industry experts.

3. The experimental equipment is backward and the practice base is in short supply. Network and new media professional as a practical professional, the requirements for photography, recording, editing, broadcasting equipment and network laboratory is quite high. In addition to the complete set-up of individual first-class colleges and universities, many colleges and universities have backward teaching equipment, lack of teaching hardware facilities, aging of existing teaching practice equipment, and lack of new network technology use equipment, which seriously restricts the sustainable and healthy development of the profession. It has brought many difficulties to teaching research and teaching reform. Especially for the network and new media majors in the liberal arts departments of second- and third-tier science and engineering schools, the problems of insufficient funds and insufficient investment in such schools are particularly prominent.

In order to respond to the needs of the society for professional talents training, colleges and universities have increased the number of practical courses in the training program, and increased the intensity of internship training. This makes the construction of practical training bases an important part of the development of the network and new media in colleges and universities. What is not matched is that the number of practice bases is small, the professional relevance is not strong, and the construction of many practical practice bases is on the surface. The practical curriculum objectives, implementation methods, and process organization are all lack of science, and they can't really play the role of the internship base.

\section{Suggestions on the development of talents for network and new media communication}

Through the analysis and investigation of the two interfaces of higher education and industry, we believe that the training of college network and new media professionals must keep pace with the times and continuously optimize, and adhere to the following basic principles.

1. Network and new media communication talent training should adhere to the value orientation of communication. Renmin University of China has formed a journalism model, Wuhan University has advocated a model of technologyism, and Fudan University has promoted a model of communication. Each of these three models has its own characteristics, which correspond to the special requirements of talents in different levels of online media practice. However, because the scope of application of online media is too wide, its tentacles have already broken through the connotation and scope of news, and it has extended to various fields and levels of human life. Due to the compatibility and inclusiveness of online media, the value orientation of communication should be more close to its connotation and extension.

2. Focus on network communication application skills training, supplemented by basic training 
in news communication. Students in the Network and New Media Communication Program at the School of Journalism and Communication generally receive basic training in news communication. Therefore, many graduates did not go to the online media, but chose newspapers and radio and television media, which reflects the diversity and comprehensiveness of the online media profession.

3. Broaden the knowledge of students and cultivate students' interest in a certain field and teamwork spirit. Due to the dozens of website channels, although the status of the news channel is respected, the job posting on the website is not concentrated on one channel of the news, but is distributed in each theme channel, and the professional position of the candidate is often unlimited, and it emphasizes a wide range of knowledge and has in-depth research and solidarity and cooperation in a certain field. Therefore, broadening the knowledge of students and cultivating students' multi-disciplinary interests and teamwork spirit should become the purpose of the network and new media profession.

\section{Summary}

In summary, in the 21 st century, under the influence of new media technologies, traditional talents can no longer meet the requirements of social development. The cultivation of innovative and entrepreneurial talents is in line with the needs of social development, economic and social progress, and represents the trend of the development of higher education in the world. Cultivating innovative and entrepreneurial talents requires us to break the traditional barriers to education, adapt to local conditions, adapt to school conditions, reform according to the school's own conditions, reflect the educational characteristics of the school, and cultivate a group of high-quality innovative and entrepreneurial talents to provide power for the development of society. In order to better promote new media development and innovation and entrepreneurship, we must base ourselves on social practice, grasp the two-way force of new media and innovation and entrepreneurship, innovate in new online media, and in the process of innovation, we will improve the network of new media and achieve a win-win situation for both.

\section{Acknowledgement}

Research Project of Jiangsu Institute of Commerce, China Project Number: JSJM15012

\section{References}

[1]Hood O, Coutts J, Hamilton G, et al. Analysis of the role of an Innovation Broker appointed by an Environmental Innovation Partnership in the cotton industry, Queensland, Australia.[C]// European Ifsa Symposium, Farming Systems Facing Global Challenges: Capacities and Strategies, Proceedings, Berlin, Germany, 1-4 April. 2014.

[2]Colvinsterling S. The Correlation between Temperament, Technology Preference, and Proficiency in Middle School Students.[J]. Journal of Information Technology Education Research, 2015, 15(2016):1-18.

[3]Lungeanu R, Stern I, Zajac E J. When do firms change technology - sourcing vehicles? The role of poor innovative performance and financial slack[J]. Strategic Management Journal, 2016, 37(5):855-869.

[4]Izmirli S, Özden|Kabakçi Yurdakul. Investigation of Prospective Teachers' Information and Communication Technology Integration Practices in Terms of Transformative Learning Theory.[J]. Kuram Ve Uygulamada Egitim Bilimleri, 2014, 14(6):2293-2303.

[5]Xu S, Wang L. Study on the role of innovative student organizations in higher vocational colleges in promoting the innovation ability of students in the context of new media[J]. Jiangsu Science \& Technology Information, 2017.

[6]Silic M. Influence of Shadow IT on Innovation[J]. Ssrn, 2015(8):68-80. 
[7]Robb C, Gandhi S J. Social Entrepreneurial Ventures: On the Edge of Chaos?[J]. Entrepreneurship Research Journal, 2016, 6(1):111-133.

[8]Amro H J, Mundy M A, Kupczynski L. The Effects of Age and Gender on Student Achievement in Face-To-Face and Online College Algebra Classes.[J]. Research in Higher Education Journal, 2015, 27.

[9]Herring S J, Cruice J F, Bennett G G, et al. Using Technology to Promote Postpartum Weight Loss inUrban, Low-Income Mothers: A Pilot Randomized Controlled Trial - Journal of Nutrition Education and Behavior[J]. Journal of Nutrition Education \& Behavior, 2014, 46(6):610-615.

[10]Mohammadi H. Social and individual antecedents of m-learning adoption in Iran[M]. Elsevier Science Publishers B. V. 2015.

[11]Cruz S S, Teixeira A A C. The neglected heterogeneity of spatial agglomeration and co-location patterns of creative employment: evidence from Portugal[J]. Annals of Regional Science, 2015, 54(1):143-177.

[12]Vlahogianni E I, Kepaptsoglou K, Tsetsos V, et al. A Real-Time Parking Prediction System for Smart Cities[J]. Journal of Intelligent Transportation Systems, 2016, 20(2):192-204.

[13]Peña-Ayala A, Cárdenas L. A Revision of the Literature Concerned with Mobile, Ubiquitous, and Pervasive Learning: A Survey[M]// Mobile, Ubiquitous, and Pervasive Learning. Springer International Publishing, 2016.

[14]Kong S C, Looi C K, Chan T W, et al. Teacher development in Singapore, Hong Kong, Taiwan, and Beijing for e-Learning in school education[J]. Journal of Computers in Education, 2017, $4(1): 5-25$. 